\title{
Urgensi Pendaftaran Penyelenggara Sistem Elektronik Bagi Pelaku Usaha E-Commerce
}

\section{"The Urgency Of Electronic System Registration For E- Commerce Entrepreneurs"}

\author{
Mohamad Rivaldi Moha ${ }^{1}$ \\ Sukarmi ${ }^{2}$ \\ Afifah Kusumadara ${ }^{3}$ \\ 1Pascasarjana Ilmu Hukum Universitas Brawijaya Malang, Jawa Timur, Indonesia. E-mail: mrivaldy.moha@gmail.com \\ ${ }^{2}$ Pascasarjana Ilmu Hukum Universitas Brawijaya Malang, Jawa Timur, Indonesia \\ ${ }^{3}$ Pascasarjana Ilmu Hukum Universitas Brawijaya Malang, Jawa Timur, Indonesia
}

\section{Info Artikel}

\section{Kata Kunci:}

Pendaftaran;

Penyelenggara Sistem

Elektronik; Pelaku Usaha

E-commerce.

\section{Cara Mengutip (APA}

Citation Style):

Moha, M.R, Sukarmi, dan

Afifah, K. (2020).

"Urgensi Pendaftaran

Penyelenggara Sistem

Elektronik Bagi Pelaku

Usaha E-commerce".

Jambura Law Review,

JALREV 2 (2): 101-119

\begin{abstract}
Abstrak
Kewajiban pendaftaran penyelenggara sistem elektronik bagi seluruh pelaku usaha e-commerce di indonesia menjadi salah satu program pemerintah dalam Peta Jalan Sistem Perdagangan Nasional Berbasis Elektronik (Road Map E-commerce) Tahun 2017-2019. Oleh karena itu, Tujuan penulisan ini untuk menguraikan pentingnya pendaftaran penyelenggara sistem Elektronik bagi pelaku usaha e-commerce di Indonesia. Penelitian ini merupakan penelitian yuridis normatif yang menggunakan pendekatan perundang-undangan, pendekatan konsep dan pendekatan perbandingan. Hasil dari penelitian ini adalah pentingnya pendaftaran penyelenggara sistem elektronik bagi pelaku usaha ecommerce ialah memudahkan konsumen dalam mengidentifikasi pelaku usaha, serta dapat membantu pemerintah dalam program pengenaan pajak bagi pelaku usaha e-commerec.
\end{abstract}


Article Info

\section{Keywords:}

Registration; The

organizer electronic

system; e-commerce

entrepreneurs.

\section{How to cite (APA}

Citation Style):

Moha, M.R, Sukarmi, dan

Afifah, K. (2020). “The

Urgency Of Electronic

System Registration for

E-Commerce

Enterpreneurs". Jambura

Law Review, JALREV 2

(2): 101-119

\begin{abstract}
Registration obligation of electronic system organizers for all actors in the e-commerce business in Indonesia to be one of the government programs in the road map of electronic-based National trading system year 2017-2019. Therefore, the purpose of this writing to describe the importance of registration of electronic systems organizers for e-commerce enterprises in Indonesia. This research is a normative juridical study that uses statutory approaches, approach concepts, and comparative approaches. The result of this research is the importance of registration of electronic systems organizers for e-commerce enterprises is to facilitate consumers in identifying business actors, and can assist the Government in the taxdeductible program for e-commerce enterprises.
\end{abstract}

(C) 2020 -Moha, Mohamad Rivaldi Under the license CC BY-SA 4.0

\section{Pendahuluan}

Perkembangan teknologi internet yang semakin pesat telah memberikan dampak yang sangat besar pada masyarakat dunia. Perkembangan ini telah mengubah berbagai macam metode konvensional dan pola hidup masyarakat menjadi lebih modern disegala bidang, seperti sosial, budaya, ekonomi, militer, administrasi serta bidang lainnya. Dengan adanya perkembangan teknologi serta kemudahan masyarakat untuk berkomunikasi dan mengakses informasi membuat peluang dan persaingan yang ada di masyarakat juga ikut bertambah. Masyarakat sekarang dituntut untuk hidup lebih modern dan ikut pada perkembangan tersebut jika tidak ingin kalah bersaing. ${ }^{1}$

Pemanfaatan teknologi internet ini juga dilakukan oleh sebagian besar masyarakat Indonesia. Hasil survei yang dilakukan oleh Asosiasi Penyelenggara Jasa Internet Indonesia yang dilakukan pada tahun 2016 menunjukan terdapat 132,7 juta pengguna internet di Indonesia, dimana sebagian besar pengguna internet tersebut berada di wilayah jawa yakni sebanyak 86,3 juta orang. Adapun pemanfaatan teknologi internet

\footnotetext{
1 Hendro Setyo Wahyudi, Mita Puspita Sukmasari. (2014). "Teknologi dan Kehidupan Masyarakat" Jurnal Analisa Sosiologi, 3 (1): 13-24.
} 
tersebut cukup beragam, dimana dari 132,7 juta pengguna internet tersebut 97,4\% diataranya menggunakan internet untuk media sosial, $96,8 \%$ untuk hiburan, $96.4 \%$ untuk mengakses berita, 93.8\% untuk kebutuhan pendidikan, 93.1\% untuk komersial, dan $91.6 \%$ diantaranya juga menggunakan internet untuk pelayan publik Indonesia. ${ }^{2}$

Selain pemanfaatan dalam bidang komunikasi dan informasi, teknologi internet juga memberikan pengaruh yang sangat kuat pada perekonomian dunia. Babak baru perekonomian modern yang lebih dikenal dengan istilah digital economics ini memberikan penawaran baru pada metode perdagangan yang lebih mudah dan efisien bagi masyarakat. ${ }^{3}$ Dahulunya pada metode perdagangan konvensional, pada umumnya proses jual-beli barang atau jasa dilakukan secara langsung dan harus ada kesepakatan antara penjual dan pembeli. Di era digital economics dengan bantuan teknologi internet, jarak seolah tidak menjadi penghalang bagi kesepakatan jual-beli tersebut dilaksanakan.

Proses perdagangan yang menggunakan internet sebagai media penghubung antara penjual dan pembeli ini lebih dikenal dengan istilah electronic commerce atau $e$ commerce. E-commerce merupakan suatu model perdagangan modern yang bersifat non-fisik atau dengan kata lain metode ini tidak menghadirkan pelaku perdagangan secara fisik dan tidak menggunakan tanda tangan asli (non-sign). ${ }^{4}$ Niniek Suparni mendefinisikan segala kegiatan-kegiatan bisnis yang menyangkut konsumen (consumers), manufaktur, service provider, dan pedagang perantara (intermidiaries) dengan menggunakan jaringan komputer merupakan e-commerce..$^{5}$ Oleh karena itu dibutuhkan suatu sistem yang mampu menjamin keamanan transaksi tersebut.

Badan Ekonomi Kreatif (Bekraf) memproyeksikan bahwa usaha-usaha perdagangan melalui sistem elektronik (e-commerce) berupa start-up dan bisnis online lainnya dapat memberikan sumbangsi bagi perekonomian negara. Badan ini memperkirakan startup dalam industri kreatif secara individu akan mampu menyumbang sebesar $12 \%$ dari Produk Domestik Bruto (PDB) dengan penyerapan sebesar 13 juta tenaga kerja baik

2 Margareta Rosa Anjani dan Budi Santoso. (2018). "Urgensi Rekonstruksi Hukum E-commerce di Indonesia”. Jurnal Law Reform, 14 (1) : 90

3 Sinta Dewi Rosadi, Zahra Tahira. (2018). “Consumer Protection In Digital Economy Era: Law in Indonesia”, Jurnal Yustisia, 7 (1): 85-97

4 Ibid.

5 Niniek Suparni. (2009). “CYBERSPACE: Problematika \& Antisipasi Pengaturannya”. Jakarta: Sinar Grafika. Hal. 30. 
yang terlibat langsung maupun tidak langsung. Dengan potensi kontribusi terhadap perekonomian nasional, maka sudah selayaknya Pemerintah harus sunggu-sungguh dalam merumuskan kebijakan untuk mendukung pertumbuhan sekaligus melindungi industri perdagangan melalui sistem elektronik tersebut. ${ }^{6}$

E-commerce di Indonesia memiliki payung hukum secara jelas dan khusus sejak 11 maret 2014 dengan disahkannya Undang-undang Nomor 7 Tahun 2014 Tentang Perdagangan. Sebelumnya aturan e-commerce hanya bertopang pada Undang-undang Nomor 11 tahun 2008 Tentang Informasi dan Transaksi Elektronik (UU ITE), yang kemudian direvisi menjadi Undang-Undang Nomor 19 Tahun 2016. Pengaturan $e$ commerce dalam undang-undang ini ditujukan agar dapat memberikan kepastian dan kesepahaman mengenai apa yang dimaksud dengan e-commerce, selain itu undangundang ini menjamin perlindungan, kepastian kepada pelaku usaha elektronik, penyelenggara e-commerce, dan konsumen dalam melakukan kegiatan perdagangan melalui sistem elektronik. Namun Aturan tersebut sifatnya masih parsial karena belum menjangkau permasalahan utama dalam penyelenggaraan e-commerce, yaitu pembayaran elektronik, kontrak elektronik dan jaminan keamanan, penyelesaian sengketa, batas negara dan hukum yang digunakan, perlindungan konsumen, pajak dan yang terutama adalah harmonisasi sistem hukum. ${ }^{7}$

Permasalahan yang dihadapi konsumen dalam aktivitas e-commerce menjadi penghambat berjalannya penyelenggaraan sistem elektronik di Indonesia. Masalahmasalah empiris yang dihadapi masyarakat seperti penipuan online, hacking serta lemahnya penegakan hukum terhadap kasus-kasus tersebut membuat konsumen tidak secara penuh terlindungi oleh hukum. Oleh karena itu sebagai bentuk preventif untuk mencegah hal tersebut, pemerintah Indonesia melalui Kementerian Perdagangan serta Kemeterian Komunikasi dan Informasi akan mewajibkan pelaku usaha e-commerce untuk mendaftarkan diri. Pendaftaran ini bertujuan untuk memudahkan pemerintah dalam mendata serta mengidentifikasi pelaku e-commerce. Para pelaku usaha $e$ commerce yang telah melakukan pendaftaran nantinya akan mendapatkan nomor identitas yang harus dicantumkan pada platform e-commerce. Kelak seluruh nomor

6 Ardiansyah. (2015). "Tantangan Hukum dan Peran Pemerintah dalam Perkembangan Bisnis Start-Up Ecommerce di Indonesia". Jakarta: Kearsipan Jurusan Magister Teknik Elektro, fakultas Pascasarjana Universitas Mercu Buana. Hal. 4.

7 Margareta Rosa Anjani dan Budi Santoso, Op.Cit., Hal. 90 
identitas yang terdaftar akan dikumpulkan oleh Kementerian Perdagangan agar bisa diakses oleh publik. Pendaftaran ini dikenal dengan Pendaftaran Penyelenggara Sistem Elektronik. ${ }^{8}$ Oleh karena itu, artikel ini hendak menguraikan pentingnya pendaftaran penyelenggara sistem elektronik bagi pelaku usaha e-commerce di Indonesia.

\section{Rumusan Masalah}

Kewajiban pelaku e-commerce di Indonesia untuk melalukan pendaftaran sebenarnya telah memiliki landasan hukum, sebagaimana yang tercantum pada Peraturan Menteri Komunikasi dan informasi Nomor 36 Tahun 2014 Tentang Tata Cara Pendaftaran Penyelenggara Sistem Elektronik dinyatakan bahwa pelaku usaha digital wajib untuk memiliki sertifikat legal, serta dalam Pasal 5 dijabarkan bahwa Penyelenggara Sistem Elektronik untuk pelayanan publik wajib melakukan pendaftaran, namun sayangnya Seperangkat peraturan tentang pendaftaran Penyelenggara Sistem Elektronik ini masih sangat umum dan luas sehingga sulit untuk menyentuh para pelaku usaha untuk melakukan pendaftaran. Hal ini dikarenakan sifat penyelenggara sistem elektronik yang diketgorikan wajib melakukan pendaftaran dijabarkan secara umum dan kurang mendetail. Dalam peraturan ini penyelenggara Sistem Elektronik dikualifikasikan sebagai sebagai setiap Orang, penyelenggara negara, Badan Usaha, dan masyarakat yang menyediakan, mengelola, dan/atau mengoperasikan Sistem Elektronik secara sendiri-sendiri maupun bersama sama kepada Pengguna Sistem Elektronik untuk keperluan dirinya dan/atau keperluan pihak lain.

Oleh karena itu berdasarkan peraturan tersebut, pelaku usaha e-commerce juga dikategorikan pihak yang wajib untuk melakukan pendaftaran, karena sifatnya yang melakukan pelayanan publik dan menggunakan media elektronik dalam mengoperasikan usahanya. Sayangnya tidak dijelaksan secara gamblang jenis-jenis ecommerce seperti apa yang diwajibkan untuk melakukan pendaftaran. Karena di Indonesia sendiri dikenal ada empat jenis e-commerce yang diakui dan dikenakan pajak oleh pemerintah yakni marketplace, online ritail, ads classified dan daily deals. Akibatnya peraturan-peraturan terkait pendaftaran sistem elektronik ini masih sangat kabur dan belum mengikat para pelaku usaha e-commerce di Indonesia untuk

\footnotetext{
8 CCNIndonesia. "E-commerce Bakal Wajib Melaporkan Data Kegiatan Usaha Ke Kemendag".

Dilansir dari https://www.cnnindonesia.com/ekonomi/20181003203116-92-335495/e-commerce-bakal-wajiblapor-data-kegiatan-usaha-ke-kemendag, diakses pada tanggal 20 Februari 2019, Pukul 14.00 WIB
} 
melakukan pendaftaran. Walaupun pendaftaran ini gratis dan dilakukan secara online, terbukti hingga saat ini pelaku penyelenggara sistem elektronik yang terdaftar baru mencapai 1241 usaha yang diantaranya adalah merupakan usaha e-commerce. ${ }^{9}$ Angka ini tentu saja tidak sebanding dengan jumlah pelaku usaha e-commerce di Indonesia yang menurut data Badan Pusat Statistik Indonesia mencapai 26,6 juta unit. ${ }^{10}$

Selain kekaburan hukum, masalah pendaftaran Penyelenggara Sistem elektronik lainya yang implikasi pada ketidakpatuhan pelaku usaha e-commerce dalam melakukan pendaftaran ialah belum adanya sanksi yang jelas bagi para pelaku ecommerce yang tidak melakukan pendaftaran serta mekanisme dan standarisasi bagi usaha e-commerce yang wajib melakukan belum ditetapkan melalui perangkat peraturan tersebut.

\section{Metode}

Artikel ini merupakan hasil penelitian dengan metode penelitian yuridis normatif yang menggunakan pendekatan perundang-undangan, pendekatan konsep dan pendekatan perbandingan. Penelitian ini menggunakan metode penelitian yuridis normatif karena peneliti ingin manganalisis kekosongan hukum dalam penyelenggaraan sistem perdagangan elektronik di Indonesia, serta dapat menjawab isu hukum tentang urgensi pembentuk an peraturan terkait tata cara penfataran usaha e-commerce di Indonesia secara normatif. Setelah bahan hukum primer, sekunder dan tersier telah dikumpulkan, selanjutnya diidentifikasi, dikualifikasikan, disederhakan dan difokuskan pada materi penelitian. selanjutnya segala pokok-pokok permasalahan yang ditemukan terkait isu dalam penelitian dideskripsikan, dan kemudian dianalisis dan telaah berdasarkan hukum materil dan dihubungkan dengan doktrin-doktrin para ahli yang dijelaskan melalui literatur-literatur hukum yang terkumpul. Teknik analisis bahan hukum yang digunakan dalam penulisan artikel adalah deskriptif-analitis. Yaitu mendeskripsikan serta menganalisis terkait urgensi dan mekanisme pendaftaran penyelenggara sistem elektronik bagi pelaku e-commerce di indonesia.

\footnotetext{
${ }^{9}$ Data diambil dari situs resmi milik Kementrian Komunikasi dan Informasi, dilansir dari https://pse.kominfo.go.id/pse-terdaftar diakses pada tanggal 20 Februari 2019, pukul 10.00 WIB

10Warta Ekonomi. "Pertumbuhan E-commerce Pesat di Indonesia". Dilansir dari https://www.wartaekonomi.co.id/read216302/pertumbuhan-e-commerce-pesat-di-indonesia.html, diakses pada tanggal 20 Februari 2019, pukul 10.15 WIB
} 


\section{Pendaftaran Penyelenggara Sistem Elektronik Bagi Pelaku Usaha E- Commerce}

Undang-undang Nomor 7 Tahun 2014 Tentang Perdaganggan merupakan landasan utama pengaturan akivitas perdagangan melalui sistem elektronik di Indonesia, maka berlaku pula asas Lex Specialis derogat legi generali terkait perdagangan melalui sistem elektronik melalui undang-undang tersebut, dengan kata lain undang-undang tersebut menjadi acuan dalam hukum bagi pelaku usaha perdagangan melalui sistem elektronik di Indonesia, ${ }^{11}$ namun pengaturan terkait perdagangan melalui sistem elektronik hanya diatur dalam dua pasal dalam undang-undang tersebut, dimana ketentuan-ketentuan lebih lanjut diatur dalam peraturan pelaksana dan peraturan pemerintah yakni melalui Peraturan Pemerintah Nomor 82 Tahun 2012 tentang Penyelenggaraan Sistem dan Transaksi, Peraturan Bank Indonesia No.11/12/ PBI/2009 tentang Uang Elektronik (Electronic Money), dan peraturan lainnya.

Salah satu contoh permasalahan yang timbul akibat kurangnya kejelasan terkait pengaturan perdagangan melalui sistem elektronik ialah pendaftaran pelaku usaha $e$ commerce serta legalitas usaha yang berimplikasi pada banyak sektor. Berdasarkan Pasal 24 ayat (1) Undang-undang 7 Tahun 2014 tentang Perdagangan bahwa "Pelaku Usaha yang melakukan kegiatan usaha Perdagangan wajib memiliki perizinan di bidang Perdagangan yang diberikan oleh Menteri”. Bentuk perizinan yang dimaksud adalah Surat Izin Usaha Perdagangan (SIUP) bagi pelaku usaha dibidang perdagangan, sebagaimana yang tercantum pada Peraturan Menteri Perdagangan Nomor 36/M DAG/PER/9/2007 tentang Penerbitan Surat Izin Perdagangan. Menurut Peraturan Menteri ini, Setiap Perusahaan yang melakukan usaha perdagangan wajib memiliki SIUP12, kecuali;

a) Kantor Cabang Perusahaan atau Kantor Perwakilan Perusahaan

b) Perusahaan Kecil perorangan yang tidak berbentuk Badan Hukum atau Persekutuan, yang diurus, dijalankan atau dikelola sendiri oleh pemiliknya atau anggota keluarga/kerabat terdekat.

\footnotetext{
11 Deky Pariadi. (2018), "Pengawasan E-Commerce dalam Undang-Undang Perdagangan dan Undang-Undang Perlindungan Konsumen". Jurnal Hukum dan Pembangunan, 48 (3): 653.

12 Sumarjono, Subarkah dan Suparnyo. (2018), "Pelaksanaan Pelayanan Perizinan Usaha Perdagangan Secara Online oleh Dinas Penanaman Modal dan Pelayanan Terpadu Satu Pintu dalam Upaya Meningkatkan Investasi di Kabupaten Kudus". Jurnal Suara Keadialan, 19 (1): 34.
} 
c) Pedagang Keliling, Pedagang Asongan, Pedagang Pinggir Jalan atau Pedagang Kaki Lima.

Pengecualian kewajiban perizinan terhadap Perusahaan Kecil perorangan yang tidak berbentuk Badan Hukum atau Persekutuan, yang diurus, dijalankan atau dikelola sendiri oleh pemiliknya atau anggota keluarga/kerabat terdekat ini tentu memberikan ketidakpastian bagi pelaku usaha e-commerce di Indonesia untuk melalukan pendaftaran perizinan karena dapat dijadikan perlindungan hukum bagi pelaku usaha perorangan di bidang e-commerce untuk tidak melakukan pendaftaran. Hal ini tentu akan menyulitkan pemerintah untuk mengontrol usaha e-commerce yang dikelola perorangan yang tidak berbadan hukum apabila banyak yang tidak melakukan pendaftaran.

Kontras dengan pengecualian pendaftaran bagi pelaku usaha perorangan yang tidak berbadan hukum, kewajiban pendaftaran bagi seluruh peluku usaha e-commerce di Indonesia diatur melalui Pasal 5 ayat (1) Peraturan Pemerintah Nomor 82 Tahun 2012 tentang Penyelenggaraan Sistem dan Transaksi yang menyatakan bahwa setiap penyelenggara sistem elektronik pelayanan publik wajib melakukan pendaftaran, namun terdapat permasalahan pada peraturan pemerintah tersebut, yakni definisi transaksi elektronik dan pelayanan publik yang terlalu luas mengingat dalam aktivitas perdagangan melalui sistem elektronik terdapat berbagai model serta kegiatan marketplace, online retail, daily deals, dan price comparison/aggregator. Sehingga tidak ada kejelasan jenis aktivitas mana dan bentuk usaha seperti apa yang dikategorikan sebagai transaksi elektronik serta wajib melakukan pendaftaran.

Penyelenggara Sistem Elektronik yang wajib melakukan pendaftaran sebagaimana sebagaimana yang tercantum dalam Pasal 5 Peraturan menteri Komunikasi dan Informatika Nomor 36 Tahun 2014 yakni; Portal, situs atau aplikasi online melalui internet yang dipergunakan untuk fasilitasi penawaran dan/ atau perdagangan barang dan/ atau jasa. Serta Sistem Elektronik yang didalamnya terdapat fasilitas pembayaran dan/ atau transaksi keuangan lainnya secara online melalui jaringan komunikasi data atau internet. Dapat diartikan bahwa pelaku usaha e-commerce yang diwajibkan untuk melakukan pendaftaran melalui pengaturan tersebut hanyalah pelaku usaha yang memiliki portal, situs atau aplikasi online. Dengan kata lain $e$ - 
commerce retail yang memperdagangkan produknya dibawah marketplace tidak perlu melakukan pendaftaran. Hal ini juga ditegaskan dengan syarat pendaftaran baik pelaku usaha yang berbentuk badan hukum maupun perorangan yang wajib mencantumkan domain usahanya. Tentu ini membuka ruang bagi pelaku usaha yang bukan berbentuk portal, situs atau aplikasi online untuk tidak melakukan pendaftaran sehingga tidak membuat para pelaku usaha e-commerce patuh untuk melakukan pendaftaran.

Pengaturan terkait pendaftaran penyelenggara sistem elektronik bagi pelaku $e$ commerce ini tentu saja dapat efektif apabila pengaturan kewajiban pendaftaran tersebut tidak terdapat kekaburan dan pertentangan terkait pihak yang dimaksudkan dalam proses pendaftaran tersebut, serta diaturnya sanksi yang tegas bagi pelaku usaha yang tidak melakukan pendaftaran serta penguatan sistem perdagangan berbasis elektronik yang aman dan terorganisir dengan baik oleh pemerintah. Kewajiban pendaftaran bagi pelaku usaha e-commerce di indonesia telah dicanangkan oleh pemerintah melalui Peraturan Presiden Tahun 74 Tahun 2017 tentang Peta Jalan Sistem Perdagangan Nasional Berbasis Elektronik (Road Map E-commerce) Tahun 2017-2019 ini, dimana pada program perpajakan terdapat salah satu kegiatan yang ingin dicapai yakni ialah penyusunan regulasi kewajiban pelaku usaha $e$-commerce untuk mendaftarkan diri termasuk pelaku usaha asing dengan tujuan mengeluarkan peraturan menteri perdagangan tentang ketentuan dan tata cara pendaftaran dan penerbitan nomor identitas pelaku usaha transaksi perdagangan melalui sistem elektronik (TPMSE).

Program ini ditargetkan rampung pada bulan september 2017, namun hingga pertengahan tahun 2019 peraturan ini belum terealisasikan. Pengaturan kewajiban pelaku usaha e-commerce untuk ini nantinya akan diatur melalui Peraturan pemerintah yang saat ini Rancangan Peraturan Pemerintah tersebut telah sudah berada di Sekretariat Negara. Salah satu tujuan utama pemerintah untuk membuat regulasi terkait pendaftaran e-commerce yakni melindungi kedua belah pihak, yaitu penjual sebagai pelaku usaha dan pembeli sebagai konsumen. Adapun beberapa alasan pendukung kenapa pengaturan pendaftaran sistem elektronik bagi pelaku usaha $e$ commerce sangatlah urgen untuk diterapkan sebagai berikut; 


\subsection{Memudahkan Konsumen Untuk Mengidentifikasi Pelaku Usaha E- Commerce}

Proses perdagangan melalui sistem elektronik (e-commerce) sering memberikan resiko yang lebih besar kepada pembeli/ konsumen dibandingkan penjual, seperti pencurian dan penjualan data konsumen oleh pelaku usaha ataupun pihak ketiga saat terjadi transaksi, terjadinya wanprestasi yang dilakukan pihak pelaku usaha, pengiriman produk yang rusak atau terlambat, iklan-iklan produk e-commerce yang tidak jujur, bahkan penipuan yang dilakukan oleh pelaku usaha fiktif.

Saat ini jaminan yang diberikan pemerintah dalam melindungi konsumen dari masalah-masalah tersebut secara yuridis selain UU ITE ialah memalui Undang-Undang Nomor 8 Tahun 1999 Tentang Perlindungan Konsumen, yang mana undang-undang ini mengatur mengenai hak-hak konsumen serta perbuatan-perbuatan yang dilarang bagi pelaku usaha. Namun sayang undang-undang ini masih memiliki kelemahan dalam menjangkau e-commerce, terlebuh dalam hal pengertian pelaku usaha. ${ }^{13}$ Dalam pasal 1 butir 3 undang-undang ini dijelaskan bahwa pelaku usaha;
"setiap orang perseorangan atau badan usaha, baik yang berbentuk badan hukum maupun bukan badan hukum yang didirikan dan berkedudukan atau melakukan kegiatan dalam wilayah hukum negara Republik Indonesia, baik sendiri maupun bersama-sama melalui perjanjian menyelenggarakan kegiatan usaha dalam berbagai bidang ekonomi."

Artinya pelaku usaha yang dimaksud pada undang-undang tersebut hanyalah pelaku usaha di bidang penyediaan dana (investor), pembuatan barang atau jasa (produser) maupun di bidang pengedaran barang atau jasa (distributor) yang memliki ruang lingkung usaha yang bergerak di wilayah hukum Republik Indonesia. Sedangkan perdagangan yang menggunakan sistem elektronik aktivitas pelaku usahanya tidak terbatasi oleh wilayah hukum tertentu.

Pelaku usaha yang berada di luar wilayah hukum Indonesia, maka aktivitas perdagangan tersebut sangat bergantung pada perjanjian yang dilakukan oleh pihakpihak terkait. Contohnya perusahaan amazon.com memberikan klausa yang menegaskan bahwa setiap transaksi yang terjadi menggunakan "the laws of State of Washington“ dengan kata lain setiap konsumen yang melakukan transaksi dengan

13 Edmon Makarim. (2003). “Kompilasi Hukum Telematika”. Jakarta: PT Raja Grafindo Persada. Hal. 244 
Amazon.com tunduk pada hukum negara bagian Washington, termasuk konsumen yang berasal dari negara lain. Oleh karena itu apabila terdapat gugatan yang ditujukan kepada pelaku usaha yang berada di luar negeri, maka gugatan itu harus diajukan kepada negara yang bersangkutan dengan menggunakan instrumen hukum perdata internasional seperti perjanjian atau yurisprudensi. ${ }^{14}$

Hal ini tentu akan menyusahkan konsumen dalam menyelesaikan permasalahanpermasalahan yang berkaitan dengan transaksi elektronik dan berimplikasi pada kerugian konsumen. Untuk dapat menghindari masalah ini konsumen pun harus cermat dalam setiap klausa yang ada pada perjanjian yang dibuat pada setiap transaksi, selain itu konsumen haruslah tahu identitas pelaku usaha serta keberadaan pelaku usaha tersebut. Dengan mengetahui identitas dan keberadaan pelaku usaha, maka konsumen dapat mengetahui akibat hukum apa yang terjadi dengan adanya transaksi yang akan dibuat.

Transaksi e-commerce digolongkan sebagai perjajian jual beli begaimana yang ada dalam Kitab Undang-Undang Hukum Perdata Indonesia, akibatnya transaksi $e$ commerce juga dapat melahirkan sebuah prestasi atau sebuah kewajiban suatu pihak untuk melakukan hal-hal yang ada dalam suatu perjanjian. Apabila salah satu pihak tidak melaksanakan prestasi atau kewajiban tersebut maka hal tersebut dikenal dengan wanprestasi. Berikut merupakan contoh-contoh wanprestasi yang dapat dilakukan oleh seorang pelaku usaha e-commerce ${ }^{15}$ :

1. Tidak melakukan apa yang disanggupi akan dilakukannya, yakni keadaan dimana penjual atau merchant tidak memenuhi kewajiban untuk menyerahkan suatu barang yang dijual kepada pembeli dan kewajiban untuk menanggung kenikmatan tenteram dan menggung cacad-cacad tersembunyi.

2. Melaksanakan apa yang dijanjikan tetapi tidak sebagaimana yang dijanjikan, yakni keaadan dimana pelaku usaha memberikan pelayanan atau tanggunjawab atas kewajiban namun tidak sesuai apa yang dijanjikan atau dipromosikan diawal sebelum transaksi.

\footnotetext{
14 AZ. Nasution. (2001). Makalah: "E-commerce dan Perlindungan Hukum, pada Seminar Aspek Hukum Perlindungan Konsumen dalam Praktek E-commerce. Jakarta. Hal. 8.

15 Edmon Makari, Op.Cit. Hal. 238-239.
} 
3. Melaksanakan apa yang dijanjikan tetapi terlambat, apabila pesanan datang terlambat tapi dapat dipergunakan maka hal tersebut dikategorikan sebagai prestasi yang terlambat, namun apabila sudah tidak dapat digunakan maka hal ini digolongkan sebagai tidak melaksanakan apa yang diperjanjikannya.

4. Melakukan sesuatu yang menurut perjanian tidak boleh dilakukannya, contohnya pelaku usaha yang berkewajiban untuk tidak menyebarkan informasi dan data diri pembeli kepada khalayak umum namun pelaku usaha melakukannya maka perbuatan tesebut digolongkan sebagai wanprestasi.

Selain permasalahan wanprestasi dan sulitnya penyelesaian sengketa e-commerce, permasalahan lain yang sering terjadi pada aktivitas $e$-commerce ialah penipuan yang dilakukan oleh pelaku usaha e-commerce atau dikenal dengan penipual online. Permasalahan ini dikategorikan sebagai tindak pidana yang merigukan konsumen secara materil.

Penipuan secara online pada prinisipnya sama dengan penipuan konvensional, namun yang membedakan hanyalah pada sarana perbuatannya yakni menggunakan Sistem Elektronik seperti komputer, internet, perangkat telekomunikasi. Sehingga secara hukum, penipuan secara online dapat diperlakukan sama sebagaimana delik konvensional yang diatur dalam Kitab Undang-Undang Hukum Pidana ("KUHP"). Dasar hukum yang digunakan untuk menjerat pelaku penipuan saat ini adalah Pasal 378 KUHP, yang berbunyi ${ }^{16}$ :

"Barang siapa dengan maksud untuk menguntungkan diri sendiri atau orang lain dengan melawan hukum, dengan memakai nama palsu atau martabat palsu, dengan tipu muslihat ataupun dengan rangkaian kebohongan menggerakkan orang lain untuk menyerahkan sesuatu benda kepadanya, atau supaya memberi hutang maupun menghapuskan piutang, diancam karena penipuan dengan pidana penjara paling lama 4 tahun."

Tindak pidana penipuan yang dilakukan melalui sarana Transaksi elektronik diatur dalam Undang-Undang Nomor 19 Tahun 2016 Atas Perubahan Undang-Undang Nomor 11 Tahun 2008 tentang Informasi dan Transaksi Elektronik. Pasal 28 ayat (1) yang berbunyi:

16 Ibid. Hal. 73 
"Setiap orang dengan sengaja dan tanpa hak menyebarkan berita bohong dan menyesatkan yang mengakibatkan kerugian konsumen dalan Transaksi Elektronik"

Dengan ancaman Pidana pada Pasal 45A ayat (1) yakni penjara pidana paling lama 6 (enam) tahun/ atau denda paling banyak Rp1000.000.000 (satu milliar rupiah). Saat ini permasalahan penipuan online di indonesia juga masih menjadi kendala dalam pelaksanaan kegiatan e-commerce dan menjadi faktor utama kurangnya keparcayaan masyarakat dalam melakukan transaksi elektronik. Secara garis besar terdapat beberapa permasalahan pada proses Transaksi Online itu sendiri, yaitu ${ }^{17}$ :

1. Konsumen tidak dapat langsung mengidentifikasi, melihat atau menyentuh barang yang akan dipesan;

2. Ketidakjelasan informasi tentang produk yang ditawarkan dan/atau tidak ada kepastian apakah konsumen telah memperoleh beberapa informasi yang layak diketahui, atau yang sepatutnya dibutuhkan untuk mengambil suatu keputusan dalam bertransaksi;

3. Tidak jelasnya status subjek hukum, dari pelaku usaha;

4. Tidak ada jaminan keamanan bertransaksi dan privasi serta penjelasan terhadap resiko-resiko yang berkenaan dengan sistem yang digunakan, khususnya dalam hal pembayaran secara elektronik baik dengan credit card maupun elektronik cash;

5. Pembebanan resiko yang tidak berimbang, karena umumnya terhadap jual beli di internet, pembayaran telah lunas di muka oleh konsumen sedangkan barang belum tentu diterima atau menyusul kemudian, kerena jaminan yang ada adalah jaminan pengiriman barang bukan penerimaan barang;

6. Transaksi yang bersifat lintas batas negara boardless, menimbulkan pertanyaan mengenai yuridiksi hukum negara mana yang sepatutnya di berlakukan.

Berdasarkan masalah-masalah tersebut maka dapat disimpulkan bahwa hak-hak konsumen cenderung tergolong rentan pada aktivitas e-commerce di indonesia. Tidak terlindunginya hak-hak konsumen juga dikarenakan tidak jelasnya status subjek

17 Rifan Adi Nugraha, et. al. (2014). “Perlindungan Hukum Terhadap Konsumen Dalam Transaksi Online”. Jurnal serambi Hukum, 08 (2): 91 
hukum dari pelaku usaha. Proses transaksi elektronik dalam e-commerce yang dilakukan tanpa tatap muka dapat membuka peluang tidak terindetifikasinya si produsen atau pelaku usaha tersebut. Sehingga konsumen sulit membedakan mana pelaku usaha fiktif dan mana yang bukan. Selain itu konsumen sulit mendeteksi lokasi pelaku usaha, dan jenis usaha tersebut. Sehingga berimplikasi pada kerugian konsumen seperti tidak dikirimnya barang yang sudah dibayar oleh pelaku usaha. ${ }^{18}$

Pelaku usaha dapat saja mencantumkan alamat atau surat elektronik melalui platform dagangan mereka, namun hal tersebut tidak dapat menjamin bahwa informasi yang dicantumkan adalah informasi yang benar atau tidak. Konsumen biasanya malukan verifikasi pelaku usaha melalui testimoni yang diberikan bekas pembeli pendahulu terkait kualitas barang dan kinerja pelaku usaha. Namun hal tersebut juga dapat difiktifkan. Oleh karena itu dibutuhkan suatu metode identifikasi pelaku usaha guna mengetahui kebenaran serta informasi terkait usaha.

Identifikasi pelaku usaha ini merupakan tindakan preventif untuk menanggulangi maslah-masalah tersebut. Saat ini proses identifikasi pelaku usaha e-commerce dapat dilakukan melalui situs jejaring internet yang disediakan oleh pemerintah melalui Komeninfo seperti https://pse.kominfo.go.id/pse-terdaftar yakni sebuah situs yang berguna untuk mengecek penyelenggara sistem elektronik yang telah melakukan pendaftaran. Namun sayangnya sampai dengan saat ini pelaku penyelenggara sistem elektronik yang terdaftar baru mencapai 1241 usaha yang diantaranya adalah merupakan usaha e-commerce.

Pendaftaran usaha pada situs ini tentu saja dapat menambahkan rasa percaya konsumen pada pelaku usaha yang terdaftar, karena pelaku usaha yang tercantum pada situs ini telah terverifkasi oleh pemerintah sebelumnya dan dapat dikatakan legal. Dengan kata lain pendaftaran bukan hanya dapat bermanfaat dalam melindungi konsumen namun juga dapat memberikan manfaat pula bagi pelaku usaha dalam hal kepercayaan konsumen dan peningkatan kredibilitas usaha.

18 Suparman (2015)," Urgensi Regulasi Komprehensif E-Commerce di Indonesia dalam Menghadapi Masyarakat Ekonomi Asean (MEA)". Jurnal Mercatoria, 8 (1): 7. 
Selain mendapatkan kepercayaan dari konsumen, pelaku usaha juga dapat meningkatkan usahanya melalui pendaan oleh pemerintah yang dicanangkan melalui program yang ada pada peta Jalan Perdagangan Melalui Sistem Elektronik. Pemerintah telah menrancang beberapa program yang bertujuan untuk meningkatkan Pendanaan dan skema pembiayaan pinjaman, serta hibah yang ditujukan untuk para pelaku usaha perintis (start-up). ${ }^{19}$ Oleh karena hal tersebut dengan melalukan pendaftaran pemerintah dapat dengan mudah melacak usaha-usaha yang layak diberikan pendanaan melalui program tersebut.

Saat ini usaha e-commerce menjadi salah satu langkah paling efisien yang dapat diterapkan pada jenis usaha UMKN, hal ini dikarenakan proses pemasaran produk yang lebih mudah, murah, luas dan cepat melalui sistem perdagangan berbasis elektronik membuat $e$-commerce menjadi solusi yang palin tepat untuk jenis-jenis usaha tersebut. Konsesus umum menggolongkan usaha perintis atau yang dikenal dengan start-up sebagai usaha kecil Menengah (UKM) apabila usaha tersebut bergerak pada bidang teknologi dengan penekanan bisnis menggunakan platform-ecommerce. Data statistik yang dikeluarkan oleh Social Research \& Monitoring (soclab.co), menunjukan bahwa potensi pasar ecommerce di Indonesia memang telah merebak ke berbagai lini, termasuk UKM (Usaha Kecil Menengah). ${ }^{20}$

\subsection{Mendukung Program Pengenaan Pajak Bagi Pelaku Usaha E-commerce}

Sejak pertanggal 1 April 2019 kewajiban pajak terhadap pelaku e-commerce telah diberlakukan melalui Peraturan Menteri Keuangan (PMK) Nomor 210/PMK.010/2018 tentang Perlakuan Perpajakan atas Transaksi Perdagangan melalui Sistem Elektronik. Pajak bagi pelalu e-commerce dikenakan pada beberapa pihak seperti; ${ }^{21}$

a) Penyedia Wadah Elektronik (Platform), Platform adalah wadah berupa aplikasi, situs web, dan/ atau layanan konten lainnya berbasis internet yang digunakan

\footnotetext{
19 Lihat Peta Jalan menetapkan Peta Jalan Sistem Perdagangan Nasional Berbasis Elektronik (Road Map Ecommerce) yang diatur melalui Peraturan Presiden Nomor 74 Tahun 2017 Tentang Peta Jalan Sistem Perdagangan Nasional Berbasis Elektronik (Road Map E-commerce) Tahun 2017-2019.

${ }^{20}$ Ardiansyah, Op. Cit., hlm 3.

21 Riris Rotua Sitorus. (2017). "Pengaruh E-Commerce terhadap Jumlah Pajak yang Disetor dengan Kepatuhan Wajib Pajak sebagai Variabel Intervening”. Media Akuntansi Perpajakan, 2 (2): 70
} 
untuk transaksi dan/ atau fasilitasi perdagangan melalui sistem elektronik ( $e$ commerce).

b) Pedagang dan penyedia jasa pada Pasar Elektronik (Marketplace), Marketplace adalah sarana komunikasi elektronik yang digunakan untuk transaksi yang ditujukan untuk melakukan kegiatan usaha perdagangan secara elektronik.

c) Platform selain marketplace yang dapat berupa online retail, classified ads, daily deals, atau media sosial.

Menurut Peraturan Menteri Keuangan tersebut penyedia paltform marketplace memiliki kewajiban berupa memiki Nomor Pokok Wajib Pajak (NPWP) adalah nomor yang diberikan kepada Wajib Pajak sebagai sarana dalam administrasi perpajakan yang dipergunakan sebagai tanda pengenal diri atau identitas Wajib Pajak dalam melaksanakan hak dan kewajiban perpajakannya. Kemudian NPWP tersebut dikukuhkan sebagai Pengusaha Kena Pajak. Selain itu penyedia jasa pula wajib Memungut, menyetor, dan melaporkan PPN dan PPh terkait penyediaan layanan platform marketplace kepada pedagang dan penyedia jasa serta penjualan barang dagangan milik penyedia platform marketplace sendiri. Penyedia Platform juga wajib Melaporkan rekapitulasi transaksi yang dilakukan oleh pedagang pengguna platform. Saat ini platform marketplace dijadikan sebagai pasar elektronik di mana pedagang dan penyedia jasa pengguna platform dapat menawarkan barang dan jasa kepada calon pembeli, Bagi pedagang dan penyedia jasa yang berjualan melalui marketplace kewajiban yang harus dipenuhi dalam hal perpajakan ialah memberitahukan Nomor Pokok Wajib Pajak kepada pihak penyedia platform marketplace. namun apabila belum memiliki NPWP, maka pengusaha dapat memilih untuk mendaftarkan diri untuk memperoleh NPWP, atau juga dapat memberitahukan Nomor Induk Kependudukan kepada penyedia platform marketplace. Untuk ketentuan pajaknya, pedagang dan penyedia jasa melalui marketplace berkewajiban untuk membayar PPh sesuai dengan ketentuan yang berlaku, seperti membayar pajak final dengan tarif $0,5 \%$ dari omzet dalam hal omzet tidak melebihi Rp4,8 miliar dalam setahun, atau apabilia pedagang tersebut dikukuhkan sebagai Pengusaha Kena Pajak dengan omzet melebihi Rp4,8 miliar dalam setahun, maka wajib dikenakan PPN sesuai ketentuan yang berlaku. ${ }^{22}$

\footnotetext{
22 Kementerian Keuangan Republik Indonesia. "Ketentuan Pajak bagi Pelaku e-commerce". Dilansir dari https://www.kemenkeu.go.id/publikasi/berita/ini-ketentuan-pajak-bagi-pelaku-e-commerce/ . Diakses pada 29 juni 2019 pukul 12.00 WIB.
} 
Di indonesia sendiri pemungutan pajak menggunakan sistem self-assestment yakni pihak wajib pajak yang melakukan penghitungan dan menilai pemenuhan kewajiban perpajakannya. ${ }^{23}$ Pemberlakuan pajak bagi pelaku usaha e-commerce di Indonesia ini tentu saja dapat menemui kendala apabila pelaku usaha e-commerce tidak dapat teridentifikasi oleh pemerintah dengan baik, terlebih lagi sifatnya yang maya dan tidak terlihat dapat menjadi faktor pendorong kurang efektifnya peraturan tersebut.

Penyedia platform marketplace dapat saja menggunakan data center yang di luar negeri yang memliki biaya yang lebih murah dibandingkan dengan data center di indonesia, serta juga dapat menggunakan domain yang bukan kode negara id (dot id) melainkan doami yang bersifat universal, sehingga menyulitkan pemerintah untuk melacak platform-platform marketplace tersebut.

Terlebih lagi pelaku usaha e-commerce yang berjualan diluar marketplace menjadi lebih sulit terdektesi karena tidak terikat pada sebuah marketplace. contohnya pelaku usaha yang memperdagangkan produknya melalui media sosial, pemerintah akan sulit melacak seluruh pedagang tersebut karena jumlah media sosial yang cukup banyak serta kemudahan pembuatan akun media sosial sehingga aktivitas promosi barang dan jual-beli antara palaku usaha dan pembeli menjadi kasat mata. Akibatnya pemrmasalahan-permasalahan yang berimplikasi pada perlindungan konsumen marak terjadi pada jenis usaha e-commerce tersebut. Oleh karena hal tersebut dibutuhkan suatu metode pendaftaran usaha e-commerce serta peraturan yang mewajibkan seluruh pelaku usahanya tanpa terkecuali pada jenis apapun untuk melakukan pendaftaran. Sehingga proses pemungutan pajak pun dapat berjalan dengan baik.

\section{Kesimpulan}

Kewajiban pendaftaran bagi pelaku usaha e-commerce di indonesia telah dicanangkan oleh pemerintah melalui Peta Jalan Sistem Perdagangan Nasional Berbasis Elektronik (Road Map E-commerce) Tahun 2017-2019 ini, dimana pada program perpajakan terdapat salah satu kegiatan yang ingin dicapai yakni ialah penyusunan regulasi

23 Melisa Rahmaini Lubis. (2017). “Kebijakan Pengaturan Pajak Penghasilan dan Pajak Pertambahan Nilai Terhadap Transaksi E-Commerce", Jurnal Ilmiah Hukum Administrasi Negara, 4 (1): 12 
kewajiban pelaku usaha e-commerce untuk mendaftarkan diri termasuk pelaku usaha asing dengan tujuan mengeluarkan peraturan menteri perdagangan tentang ketentuan dan tata cara pendaftaran dan penerbitan nomor identitas pelaku usaha transaksi perdagangan melalui sistem elektronik (TPMSE).

Pendaftaran PSE bagi pelaku usaha e-commerce dapat dimanfaatkan oleh pemerintah dalam mengontrol pelaku usaha dalam hal perizinan dan perpajakan. Lebih dari itu dengan diaturnya pendaftaran PSE bagi pelaku usaha diharapkan dapat memberikan perlindungan hukum atas hak-hak konsumen dan tanggung jawab pelaku usaha $e$ commerce.

\section{Referensi}

Anjani, Margareta Rosa dan Budi Santoso. (2018). "Urgensi Rekonstruksi Hukum Ecommerce di Indonesia”. Jurnal Law Reform, 14 (1) : 89-103.

Ardiansyah. (2015). "Tantangan Hukum dan Peran Pemerintah dalam Perkembangan Bisnis Start-Up E-commerce di Indonesia". Jakarta: Kearsipan Jurusan Magister Teknik Elektro, Pascasarjana, Universitas Mercu Buana.

CCNIndonesia. (2018). E-commerce Bakal Wajib Melaporkan Data Kegiatan Usaha Ke Kemendag. Dilansir dari https://www.cnnindonesia.com/ekonomi/20181003203116-92-335495/ecommerce-bakal-wajib-lapor-data-kegiatan-usaha-ke-kemendag. Diakses pada tanggal 20 Februari 2019, Pukul 14.00 WIB

Hendro Setyo Wahyudi, Mita Puspita Sukmasari. (2014). “Teknologi dan Kehidupan Masyarakat" Jurnal Analisa Sosiologi, 3 (1) : 13-24

Kementrian Komunikasi dan Informasi. (2019). "Data Pendaftaran PSE”. Dilansir dari https://pse.kominfo.go.id/pse-terdaftar. Diakses pada tanggal 20 Februari 2019, pukul 10.00 WIB

Lubis, Melisa Rahmaini. (2017). “Kebijakan Pengaturan Pajak Penghasilan dan Pajak Pertambahan Nilai Terhadap Transaksi E-Commerce", Jurnal Ilmiah Hukum Administrasi Negara, 4 (1): 1-15.

Makarim, Edmon. (2003). “Kompilasi Hukum Telematika”. Jakarta: PT Raja Grafindo Persada.

Nasution, AZ. (2001). "E-commerce dan Perlindungan Hukum (Makalah pada Seminar Aspek Hukum Perlindungan Konsumen dalam Praktek E-commerce). Jakarta.

Nugraha, Rifan Adi, et.al . (2014). "Perlindungan Hukum Terhadap Konsumen Dalam Transaksi Online”. Jurnal serambi Hukum, 8 (2): 91-102. 
Pariadi, Deky. (2018). "Pengawasan E-Commerce dalam Undang-Undang Perdagangan dan Undang-Undang Perlindungan Konsumen". Jurnal Hukum dan Pembangunan, $48(3): 651-669$.

Peta Jalan menetapkan Peta Jalan Sistem Perdagangan Nasional Berbasis Elektronik (Road Map E-commerce) yang diatur melalui Peraturan Presiden Nomor 74 Tahun 2017 Tentang Peta Jalan Sistem Perdagangan Nasional Berbasis Elektronik (Road Map E-commerce) Tahun 2017-2019.

Sinta Dewi Rosadi, Zahra Tahira. (2018). “Consumer Protection In Digital Economy Era: Law in Indonesi a”, Jurnal Yustisia, 7 (1): 85-97

Sitorus, Riris Rotua. (2017). "Pengaruh E - Commerce terhadap Jumlah Pajak yang Disetor dengan Kepatuhan Wajib Pajak sebagai Variabel Intervening", Media Akuntansi Perpajakan, 2 (2) : 64-80.

Sumarjono, et. al. (2018). "Pelaksanaan Pelayanan Perizinan Usaha Perdagangan Secara Online oleh Dinas Penanaman Modal dan Pelayanan Terpadu Satu Pintu dalam Upaya Meningkatkan Investasi di Kabupaten Kudus". Jurnal Suara Keadilan, 19 (1) : 31-41.

Suparman. (2015). "Urgensi Regulasi Komprehensif E-Commerce di Indonesia dalam Menghadapi Masyarakat Ekonomi Asean (MEA)”. Jurnal Mercatoria, 8 (1) : 75-90.

Suparni, Niniek . (2009). “CYBERSPACE: Problematika \& Antisipasi Pengaturannya”. Jakarta: Sinar Grafika.

Warta Ekonomi. (2019). "Pertumbuhan E-commerce Pesat di Indonesia". Dilansir dari https://www.wartaekonomi.co.id/read216302/pertumbuhan-e-commerce-pesat-diindonesia.html. Diakses pada tanggal 20 Februari 2019, pukul 10.15 WIB 